\title{
Early Embryonic Development of the Liver of the One-Humped Camel (Camelus dromedarius)
}

\section{Enas Ahmed Abd El- Hafez}

\author{
Lecturer of Histology, Department of Anatomy \& Histology, Faculty of Veterinary \\ Medicine, Assiut University, Assiut, Egypt.
}

Received in July 2009, accepted for publication January 2010

\begin{abstract}
The present study was carried out to highlight the histomorphological structure of the liver of the one-humped camel during early embryonic life. Samples were collected from pregnant shecamles after slaughtering and evisceration. Different embryonic stages were taken and the crown to rump (CVR) length was measured to the nearest millimeter (ranging from 7 to $185 \mathrm{~mm}$ ). Morphological study revealed that the liver primordium appeared at $7 \mathrm{~mm}$ CVR length fetuses. At $12 \mathrm{~mm}$ CVR length the liver was related cranially to the septum transversum and heart, caudally to the primitive spleen, mesogastrium, and primitive stomach and to the lesser omentum while dorsally it was related to the mesonephrous and ventrally to the floor of the abdominal cavity. Lobation of the liver appeared at fetal lengths of $50 \mathrm{~mm}$ CVR length. Histological study revealed that the liver parenchyma consisted of a mass of hepatic foci, haemopoietic cells and irregular wide blood spaces. The primordium of Glisson's capsule appeared in fetuses of $75 \mathrm{~mm}$ CVR length. Megakaryocytes were noticed among hepatocytes and heamopoietic foci. Sections stained with the Giemssa stain revealed group of mast cells among hepatocytes. Hepatic tissue stained by Methyl green pyroninn
\end{abstract}

stained revealed that hepatocytes showed methyl green positive materials while haemopoietic cells showed pyrinophilic positive granules at $12 \mathrm{~mm}$ CVR length fetuses. Small sized mitochondrial granules appeared in the cytoplasm of the hepatocytes stained with Iron haematoxylin in fetuses of $12 \mathrm{~mm}$ CVR length. Hepatocytes were faintly stained with PAS. Electron microscopic study revealed that the hepatocytes of $185 \mathrm{~mm}$ CVR length camel fetuses contained large glycogen globlules in addition to abundant mitochondria. Histomorphometric studies were applied to compare the mean number of hepatic foci to that of haemopoietic foci and also to measure the number and size of megakaryocytes.

\section{Key words}

Prenatal development, Liver, Camel.

\section{Introduction}

The liver is a vital organ for mammalian species. It is the site of metabolic processing of all nutrients consumed by the animal. The hepatic tissues have a great capacity of regeneration and compensation for increased metabolic demands (Jones and Spring-Mills, 1977). 
The histogenesis of the liver has been studied by several authors Glimour ,(1941); Elias (1952) ;Mc Cuskey (1968); Janes (1970); Hamilton and Mossman(1972); Babic and Rode, (1977); Mohamed et al. (1986); Khalil et al. (1987) Anwar et al.(1989); Godlweski, et al. (1992); Moustafa and Ahmed (1995); and Abdel-Moniem, et al. (2000).

Studies on the one-humped camel have been in the circle of concern of many Egyptian authors for many years. Due to lack of information about the development of camel liver in the available literature, this investigation was undertaken to give more information about the morphological and histological changes in the camel liver during the early embryonic life ( 7 to $185 \mathrm{~mm}$ ) CVR length.

\section{Materials and Methods}

The materials employed in this study originated from the liver of 25 camel fetuses of both sexes ranging from 7 to $185 \mathrm{~mm}$ CVR length. The gestational stage was estimated on the basis of crown rump CVR length. The fetuses were obtained from pregnant she camels (one humped camel), slaughtered at different stages of gestation. The fetuses were removed shortly after evisceration and the crown to rump length was measured to the nearest $\mathrm{mm}$. The intact embryos were taken and fixed in $10 \%$ neutral buffered formalin and Bouins fluid for light microscopic study. After proper fixation the materials were dehydrated, cleared and embedded in paraffin wax. Sections were cut at 5-7 $\mu \mathrm{m}$ and stained with different histological stains. Hematoxylin and Eosin stain for studying of the histological structure of the tissue (Harris, 1898), Crossmans trichrome stain for detection of collagen fibers (Crossman, 1937), the PAS tech- nique for carbohydrate detection (Mc Manus, 1946), Methyl green pyronin stain for detection of both DNA and RNA cells (Bancroft, 1975), Giemssa stain for detection of mast cells (Raphael, 1977) and Iron Haematoxylin stain for detection of mitochondria in liver cells (Bancroft's, 1975).

\section{Electron microscopy}

Liver from various developmental stages $(75,125,185) \mathrm{mm}$ CVR lengths was cut into small pieces (approximately 2 $\mathrm{mm}$ ) and fixed in $2.5 \%$ glutaraldehyde in $0.1 \mathrm{M}$ sodium cacodylate buffer, at $\mathrm{pH} 7.4$ for at least 3 hours at room temperature. The fixed tissues were rinsed several times in cacodylate buffer, postfixed in $1 \%$ osmium tetroxide, dehydrated in ascending grades of acetone $(50,70,80,90$ and 100\%) and embedded in Epon resin. Ultra-thin sections were cut with a diamond knife using a Reichert OMU2 Ultramicrotome. Sections were mounted on copper grids, stained with a $5 \%$ aqueous solution of uranyl acetate for 10 minutes, washed with distilled water and stained with Reynold's lead citrate for 10 minutes. Sections were examined under a Philips 300 transmission electron microscope.

\section{Histomorphometric analysis:}

Studies were applied on representative stained sections from all developmental stages using a Leica Q500 MC Image analysis system. .

Measurments included;

1- The mean number of hepatic foci / unit area.

2- The mean number of haemopoietic foci/ unit area.

3- The mean number of megakaryocytes/ unit area.

4- The mean size of megakaryocytes/ $\mu \mathrm{m}$.

(Unit area $=$ microscopic field. ) 


\section{Results}

\section{7 - $9 \mathrm{~mm}$ CVR length fetuses:}

At this early stage of development the primordium of the camel liver appeared as a mass between the pericardium cranioventrally and the mesonephrous caudodorsally (Fig 1). At this stage the septum transversum could not be distinguished yet.

Histologically the hepatocytes were organized in the form of interlacimg solid strands separated by irregular blood spaces (Fig 2).

\section{2 -19 mm CVR length fetuses:}

At this stage of intra-uterine life, the liver was related cranially to the septum transversum and heart, caudally to the primitive spleen, mesogastrium, and primitive stomach and to the lesser ometum. Dorsally it was related to the mesonephrous and ventrally to the floor of the abdominal cavity (Fig 3 ).

Histological observation showed that, the liver primordium was composed of two different cellular elements: the hepatocytes and the haemopoietic cells in between there are irregular blood spaces (Fig 4).

The hepatocytes were arranged in anastomosing cords whose cells were polyhedral in shape with moderately acidophilic cytoplasm, large rounded nuclei and vesicular nucleoli. They were organized in the form of interlacing solid strands, separated by irregular blood spaces. These spaces had wide lumina and were lined by primitive endothelium (Fig 5).

The haemopoietic cells appeared dispersed between the liver parenchyma. These cells were rounded in shape with deeply stained centrally located relative- ly large rounded nuclei and formed the primary elements of haemopoietic foci (Fig 6).

Sections stained with Iron haematoxylin showed large numbers of small sized mitochondria in the cytoplasm of the hepatocytes (Fig 7).

\section{5 - $38 \mathrm{~mm}$ CVR length fetuses:}

At this stage of development, the liver became compact having a cranial convex surface and a caudal visceral irregular one. The dorsal border was thick and flat to come in contact to the dorsally located mesonephros. The ventral border was thin and related to the floor of the abdominal cavity where the umbilical vein entered the liver continuing within the liver parenchyma as the ductus venosus (Fig 8).

Histological examination revealed that at this stage of intra-uterine life, the liver appeared to be more heavily invested by haemopoietic cells as well as having more blood spaces between the hepatic cords.

Some of these blood spaces were large, irregular and had wide lamina lined by primitive endothelium that was represented by a single one layer of flattened cells with oval nuclei. These spaces were observed to be continuous with slit-like openings into liver sinusoids (Fig 9). Megakaryocytes were observed among haemopoietic cells. These were large cells with lobulated nuclei, showed a PAS positive reaction, while the surrounding hepatocytes were only faintly stained (Fig 10). The RNA in the cytoplasm of hepatocytes and haemopoietic cells showed very distinct pyrinophilia and the DNA in the nuclei was strongly positive to methyl green (Fig 11a).

\section{0 - $75 \mathrm{~mm}$ CVR length fetuses:}


At this stage of development the liver was greatly enlarged occupying most of the abdominal cavity. It extended from the diaphragm cranially to the pelvic inlet caudally (Fig 12). Lobation of the liver began to appear. The left lobe was definable as the part of the liver on the left side of the umbilical vein, the intermediate lobe was medial to the umbilical vein and the right basic loop was separated from the intermediate one by a deep fissure (Fig 12).

Free cords of hepatic cells started to arrange themselves radially towards the developing central veins. The hepatic cells were larger in size and some of them showed mitotic activity (Fig13). The megakaryocytes were of great size with prominent lobulated nucleus (Fig 14). The liver appeared to be covered by mesenchymal cells represented by one layer of flattened cells with oval nuclei forming the primordium of Glisson's capsule. Very fine collagenous fibers were condensed in the capsule (Fig15a, b).

Examination of sections stained with the Giemssa stain revealed small numbers of mast cells present among hepatocytes, which were characterized by metachromatic cytoplasmic granules (Fig 16a).

\section{0 - $125 \mathrm{~mm}$ CVR length fetuses:}

At this age the liver was greatly enlarged occupying most of the abdominal cavity and still had the same relations. The histological picture was the same as in the previous age but with an increase in the size of hepatocytes and condensation of the haemopoietic foci. Mast cells became numerous and were arranged in groups among the haemopoietic foci ( Fig 16b).

Examination of Iron haematoxylin stained sections showed that mitochon-

J. Vet. Anat. drial granules became numerous and larger than those observed in the previous stage.

\section{0 -185 mm CVR length fetuses:}

At this stage of development the liver was characterized by a well defined hepatic laminae arranged in radiating rows around the central veins. Most of these veins were filled with mature red blood cells. The hepatocytes were larger in size and showed high mitotic activity (Fig 17).

Trials for detection of the developing bile duct system were not successful till the end of this developmental stage.

Sections stained with methyl green pyronin stain revealed more intense reaction of RNA in the cytoplasm of hepatocytes and strong reaction of DNA in the cytoplasm of haemopoietic cells (Fig 11b).

\section{Electron microscopy study:}

Ultrastructural studies showed that at $125 \mathrm{~mm}$ CVR length the liver parenchyma contained, hepatocytes and haemopoietic cells. The hepatocytes were large cells with large nucleous their cytoplasm filled with mitochondria and rough endoplasmic reticulum. These were cells with true hepatocyte features (cytoplasmic glycogen deposits and low nucleus-to-cytoplasm ratio), but the haemopoietic cells were numerous and characterized by a clear nucleus with well delineated nucleoli and the presence of numerous mitochondria and extensive rough endoplasmic reticulum. (Fig 18). In fetuses of $185 \mathrm{~mm}$ CVR length the hepatocytes were characterized by the presence of cytoplasmic glycogen deposits. The blood sinusoids were obvious and lined by incomplete layer of flat endothelial 
cells that bulged into their lumina (Fig 19).

\section{Histomorphometric analysis:}

Morphometric study revealed that in fetuses of $9 \mathrm{~mm}$ CVR length, the mean number of the developing hepatic foci was 35.4/unit area while that of haemopoetic foci was 9.4/ unit area. With the advancement of age the mean number of hepatic foci decreased while that of haemopoietic foci increased reaching 30.08 and 10.32/ unit area respectively. A marked decrease in the mean number of hepatic foci was noticed at $75 \mathrm{~mm}$ CVR length. By the stage of $125 \mathrm{~mm}$ CVR length camel fetuses, there was further decrease in the number of hepatic foci and further increase in the number of haemopoietic foci. The maximum decrease in the mean number of hepatic foci in this study was recorded at fetuses of $185 \mathrm{~mm}$ CVR length (20.97) while the mean number of haemopoietic foci reached its maximum increase at this stage of development (16.7) (Table 1 \& Histogram 1).

The mean number of megakaryocytes recorded its maximum value in fetuses of $50 \mathrm{~mm}$ CVR length as it reached 2.9/ unit area. In addition, the mean size of megakaryocyte was the largest at this stage of development, 61.60 $\mu \mathrm{m}$ in diameter (Table 2 \& Histogram 2).

Unit area $=$ microscopic field.

Table 1 \& Histogram 1 :Mean number of hepatic foci/unit area \& Mean number of haemopoietic foci/unit area.

\begin{tabular}{|c|c|c|}
\hline $\begin{array}{c}\text { CVRL } \\
\text { Imm }\end{array}$ & $\begin{array}{c}\text { MEAN NO OF } \\
\text { HAMOPOIETIC } \\
\text { FOCI/ UNIT } \\
\text { AREA }\end{array}$ & $\begin{array}{c}\text { MEAN } \\
\text { NO.OF } \\
\text { HEPATIC } \\
\text { FOCI/ } \\
\text { UNIT } \\
\text { AREA }\end{array}$ \\
\hline 9 & 9.4 & 35.4 \\
\hline 12 & 9.6 & 34 \\
\hline 25 & 10.01 & 31.2 \\
\hline 38 & 10.32 & 30.08 \\
\hline 45 & 11 & 28.33 \\
\hline 50 & 11.09 & 28.6 \\
\hline 75 & 12.87 & 23.67 \\
\hline 90 & 13.05 & 22 \\
\hline 125 & 13.88 & 21.5 \\
\hline 140 & 14.6 & 20.45 \\
\hline 185 & 16.7 & 20.97 \\
\hline
\end{tabular}




\begin{tabular}{|c|c|c|}
\hline CVRL/mm & $\begin{array}{c}\text { MEAN NUMBERE OF } \\
\text { MEGAKARYOCYTES/ } \\
\text { unit area }\end{array}$ & $\begin{array}{c}\text { MEAN SIZE OF MEGAKA- } \\
\text { RYOCYTE/ } \boldsymbol{\mu m}\end{array}$ \\
\hline 9 & 0.7 & 39.80 \\
\hline 12 & 0.9 & 50.41 \\
\hline 25 & 1.3 & 49.39 \\
\hline 38 & 1.1 & 50.06 \\
\hline 45 & 1.2 & 55.80 \\
\hline 50 & 2.9 & 61.60 \\
\hline 75 & 1.6 & 58.26 \\
\hline 90 & 0.9 & 53.04 \\
\hline 125 & 1.1 & 50.41 \\
\hline 140 & 0.9 & 44.98 \\
\hline 185 & 0.6 & 45.52 \\
\hline
\end{tabular}

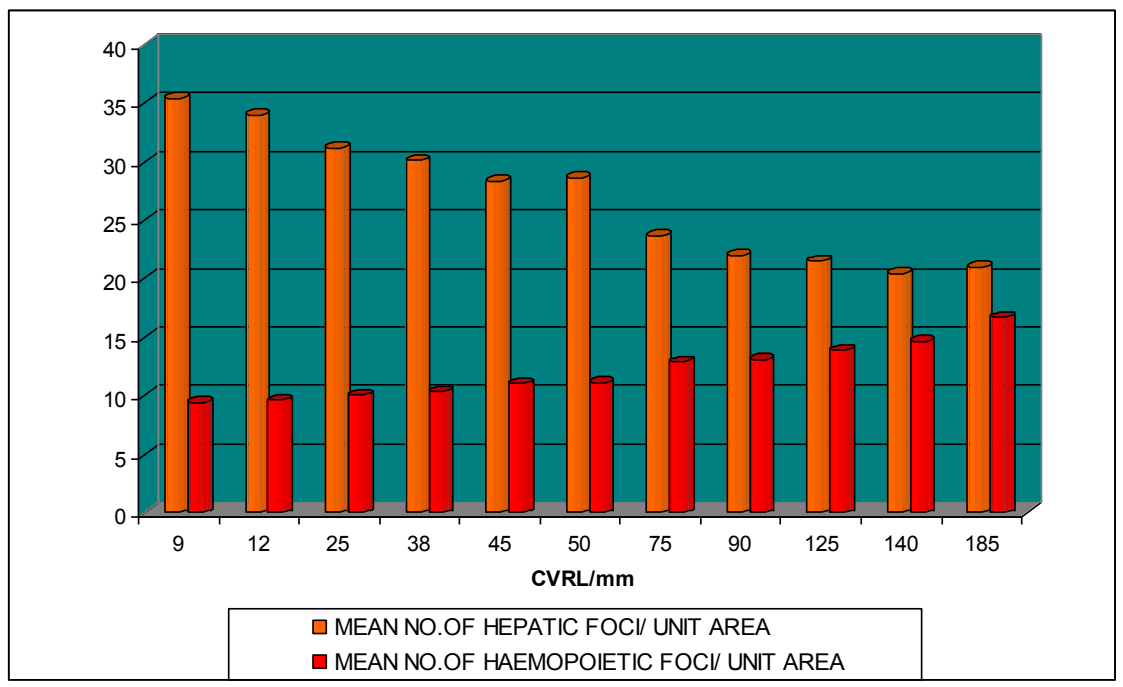

Table 2 \& Histogram 2: Mean number of megakaryocytes/unit area \& Mean size of megakaryocytes/ $\mu \mathrm{m}$

\section{Discussion}

The present study revealed that in the earliest stages of intra-uterine life (7-9 $\mathrm{mm}$ CVR length), the liver primordium developed as a hepatic diverticulum from the endoderm of the foregut. This

J. Vet. Anat. is in agreement with the previous studies in different animals (Watt et al., 2007; Abdel Moniem et al., 2000; Moustafa et al., 1995; Godlweski, 1992; Khalil et al., 1987; Mohamed,et al., 1986; O'Rahilly, 1978 and Arey, 1974). The liver of camel is covered by the thin Glisson's capsule, which first appeared 
in fetuses of $75 \mathrm{~mm}$ CVR length. The Glisson's capsule was formed of one layer of flattened cells with oval nuclei, the same result was recorded by Moustafa et al (1995), in the dog.

The development of the liver parenchyma in the present study was described as a proliferation of cells from the somatic end of the hepatic diverticulum, as small irregular masses of anastomosing cords. These increased in length and formed from large number of polyhedral cells (hepatocytes) which were radially arranged around central vein in fetuses of $75 \mathrm{~mm}$ CVR length. The same results were obtained by Bremer (1906), Bloom (1926), Sesern (1972), El-Morsy et al. (1979), Mohamed, et al (1986) and Khalil, et al. (1987) recorded the same findings in camel fetuses of $18 \mathrm{~cm}$ CVR length. In addition, El Morsy et al (1979) found that the hepatocytes were in the form of coalesced liver cords in week $12^{\text {th }}$ in the human embryo.

Similar to equine species (Rooney, et al.,1967) but different from ruminant species (Habel, 1989), but in agreement with Abdel Moniem, et al. (2000), the liver of the camel lacks a gall bladder which was never observed even in the youngest available fetuses.

Mitotic figures were frequently observed in the cellular elements of the developing liver in all ages studied. This phenomenon reflects the active cellular proliferation within the camel fetuses.
This study showed that the megakaryocytes were large cells with lobulated nuclei, first observed in camel fetuses of $25 \mathrm{~mm}$ CVR length, increasing in size and number until they reached their maximum number in fetuses of $50 \mathrm{~mm}$ CVR length. Then, they began to decrease in number with the advancement of age. In this respect Khalil, et al. (1987) noticed megakaryocytes in fetuses of $3.8 \mathrm{~cm}$ CVR length while Mohamed, et al. (1986) noticed them in fetuses of $40 \mathrm{~cm}$. Many megakaryocytes and megakaryoblasts were observed by Osman et al. (1985), in buffalo fetal liver at $3.2 \mathrm{~cm}$ CVR length. Paone et al. (1975), stated that the number of megakaryocytes decreased after the $9^{\text {th }}$ day. The same authors added that the megakaryocytes had one to four nuclei and occasionally multi-lobed or polymorphous nuclei.

Mast cells appeared in fetuses of 50 $\mathrm{mm}$ CVR lengths where they were few and singly arranged among the hepatocytes, then they increased in number and appeared in groups in the liver parenchyma of $125 \mathrm{~mm}$ CVR length fetuses. These results are in accordance with those obtained by Khalil, et al. (1987) and Mohamed, et al. (1986). They suggested that the presence of the mast cells sheds light on three important possibilities, first, they might develop from the liver in its role as a hemopoietic organ; second, they have a role in the development of the hepatic stroma in growth and regeneration, primarly of connective tissue; third, they represent progenitors of B-lymphocytes as immune producing cells as well as 
their performance of cellular immune reaction. Davis (1976) suggested that, the mast cells are preivascular and secrete anticoagulant directly through the vessels wall.

In the present study the hepatocytes showed faint PAS positive materials at all stages of development under study, a finding in agreement with Khalil, et al. (1987) who stated that the hepatocytes showed a faint reaction to PAS in fetuses of $4.7 \mathrm{~cm}$. However, Osman et al. (1984) observed strong PAS positive materials in hepatocytes of buffalo fetuses as small as $3.2 \mathrm{~cm}$ CVR length. These PAS + reactions may be due to deposition of glycogen in the cytoplasm of hepatocytes.

In this study the pyrinophilic positive material (RNA) appeared in fetuses of $12 \mathrm{~mm}$ CVR length while the nuclei of haemopoietic foci showed strong reaction with methyl green (DNA) and a moderate reaction in the nuclei of hepatocytes. This reaction of both pyrinophil and methyl green increased in intensity with the advancement of fetal life. These findings are in agreement with those of Khalil et al. (1987). In this respect, Osman et al. (1984) noticed pyrinophilic positive materials in the hepatocytes of buffalo fetuses at $2.7 \mathrm{~cm}$ CVR length which increased in $12 \mathrm{~cm}$ CVR length fetuses.

The present study revealed mitochondreal granules in hepatocytes stained with the iron haematoxylin stain. These granules were few in the fetuses of 12 $\mathrm{mm}$ CVR length, but increased in number and size in fetuses of 125 and 185 $\mathrm{mm}$ CVR length. This finding assured the demand of hepatocytes to the 'energy to cope with the activity during development.

Ultrastructural studies confirmed the presence of large numbers of mitochondria in the developing hepatocytes and the presence of cytoplasmic glycogen deposits. These results are in accordance with Kovanov et al. (1975) who stated that glycogen granules are found in the embryo hepatic cells from 7-8 weeks of intrauterine development in human hepatocytes in early prenatal ontogenesis.

Morphometric studies revealed that with the advancement of fetal life, the mean number of haemopoietic foci/ unit area increased at the expense of the mean number of hepatic foci / unit area. These results are in agreement with those of Moustafa, et al.(1995) who stated that the relative volume occupied by the hepatocytes decreased from about $60 \%$ at $25-30 \mathrm{~mm}$ CVR length dog embryos. To about $30 \%$ at $50-60$ $\mathrm{mm}$ CVR length. This suggests that the increase in liver volume at this stage of development is more due to the increase in haemopoietic foci than the increase in hepatocytes. This offers further support to Sadler (1985) who stated that the marked increase of the liver weight at 10 weeks intrauterine life could be attributed to the presence of large number of $s$ haemopoietic cells forming sinsoids. He also reported that haemopoietic cells form large nests lying between the hepatic cells and the wall of the sinusoids. 


\section{References}

Abdel-Moniem, M.E., Alam Edin, M.A., Yousria Abdel-Rahman and El-Nady F.A.M (2000): Changes in the topography of the liver of one-humped camel during the prenatal life. Assiut vet. Med.J.Vol.44 No.87, October.

Anwar, M.F; Hamid, S.H.; El-Sayed, E.H. and Zohyd, A.S.E. (1989): A histological study of the postnatal development of the liver of albino rat. Egypt J.Histol., 12(1):3-11.

Arey, L.B (1974): developmental anatomy: A textbook and laboratory manual of embryology. $7^{\text {th }}$ ed. W.B. Saunders Co., Philadelphia and London.

Babic, K and Robe, B. (1977): Further histochemical studiesof the bovine fetal liver.Zbl. Vet. Med.C. $6(1): 93$.

Bancroft, J.D. (1975): Histochemical techniques. $2^{\text {nd }}$, Ed.Butterworth $s$ London and Boston.

Bloom, J.L.(1926): The embryogenesis of human bile cappillaries and ducts. Am.J.Anat, 36:451-456.

Bremer, J.L.(1906) : Description of a four millimeter human embryo. Am. J. Anat.-, 5: 459-480.

Crossman, G. (1937): A modification of mallory connective tissue stain with discussion of the principle involved. Anat. Rec., 69: 33-38. Cutts.J.H .

Davis,M.J.(1976): Mast cell distribution in oraltissues of germ-free VS. conventional. Beqgle dogs J. Periodontol. 4:47.

Elias, H. and Petty, D. (1952): Gross anatomy of the blood vessels and ducts within the human liver. Amer. J. Anat. 90:59-111.

El-Morsy, A.S.; Ahmed, O.S. and $\mathrm{Na}$ da, H.F. (1979): Histo- logical study of the human fetal liver. Egypt. J. Hist., 2 (2): 139-14

Glimour, J.R. (1941): normal haemopoiesis in intrauterine and neonatal life. J.Path and Bact., 52:25.

Godlweski, G.; Gaubert-Gristol, R, and Rowy, S. (1992): Liver development in rat during the embryonic period (Carnegie stages 11-14).Acta Anat., 144:45-50.

Habel, R.E.(1989): Guide to the dissection of domestic ruminants. $4^{\text {th }}$ ed. Ithaca, N.Y. published by the author.

Hamilton, W.J. and Mossman ,H.W. (1972): Human embryology. 4th Ed.,P.339.Heffer and Sons Ltd., Cambridge. Great Britain.

Harris,H.E. (1898): Cited after Drury \& Walngton(1967) Carleton's Histological technique 4th Ed. Oxford Univ. Press., New York, Toronto.

Janes.R.O. (1970):Ultrastructural anal ysis of hepatic hemopoiesis in fetal mouse.J. Anat, 107: 310.

Jones, A.I. and Spring $\square$ Mills, E. (1977): The liver and gall bladder. Text book of Histology $4^{\text {th }}$ ed., Weiss, L. \& Green R.O., McGraw-Hill Book Company.

Khalil.F.K.A, Mansour. S.S.E., Ibra him A.M. (1987): Histological and Histochemical Studies On The Liver Of Developing Dromedary. M.V.Sc. Thesis Faculty of veterinary medicine Zagazig University.

Kovanov VV, Korolec VV, Razumnaia TA, Zymaleva OG (1975): [UItrastructure of human hepatocytes in early prenatal ontogenesis. Arkh Anat Gistol Embriol 
Mc Cuskey.R.S (1968): Dynamic mi croscopic anatomy of fetal liver erythropoiesis. Anat. Rec., 161: 267.

McManus, J.F.A. (1946): Histological demonstration of mucin after periodic acid. Nature (London).158: 202.

Mohamed, A.H.; Baready, M.H.; Am mar, S.M.S.; Balah, A.M. and Ewais, M.S.S. (1986): Prenatal development of the onehumped camel (Camelus dromedarius). Egypt. J. Hist., 9 (2): 225-235.

Moustafa M.N.K. and M.G. Ahmed (1995): Early embryonic development of the liver of dog. Egypt. J. Anat., Vol. 18 (1), 3553, January.

O'Rahilly, R. (1978): The timing and sequence of events in the development of the human digestive system and associated structures during the embryonic period proper. Anat. Embry.153: 132-136.

Osman A.H.K. Dougbag,A.S. and kassem, A. (1984): Organogenesis of the fetal liver of the Egyptian water buffalo (Bos Bubalis L.) Egy. Anat. Soc. 7th conference.

Paone, D.B.; Cutty J.H. and Krause, W.J. (1975): Megakaryocytopoiesis in the liver of the developing Opossum (Didelphis Vir-
ginana).J. Anat., 120 (2): 239255.

Raphael, S.S. (1977): Lynch's medical laboratory technology,- 3rd Ed.,- II: 979,- W.B. Saunders Co., Philadelphia, London, Toronto. Egypt. J. Anat., vol. 18 (1), 35-53. January. Aug; 69 (8) : 5-10.

Rooney, G. R., Sack, W.O. and Hobel, R.E.(1967): Guide to dissection of the horse . Ithaca, N.Y. Published by Vet Textbooks.

Sadler, T.W.(1985): Longman's medi cal embryology $.5^{\text {th }}$ ed . Williams \& Wilkins, Babltimore Hong Kong,Sydney.

Samir Fouad, M., El-Keshawy and sdelim,A. (1984): Histological and Histochemical Studies On The Liver Of one humped camel (Camelus dromedarius). Vet. med. J..32 (1) 313:326. Butter Worths. London and Boston.

Sesern.C.B.(1972): A morphological study of the development of the human liver. II-Establishment of liver parenchyma, extra hepatic ducts and associated venous channels: Am. J. Anat., 133:85108.

Watt A.J., Zaho R., Li J. and Dunken, S.A.( 2007): Development of the mammalian liver and ventral pancreas. BMC Developmental biology $7: 37$. 


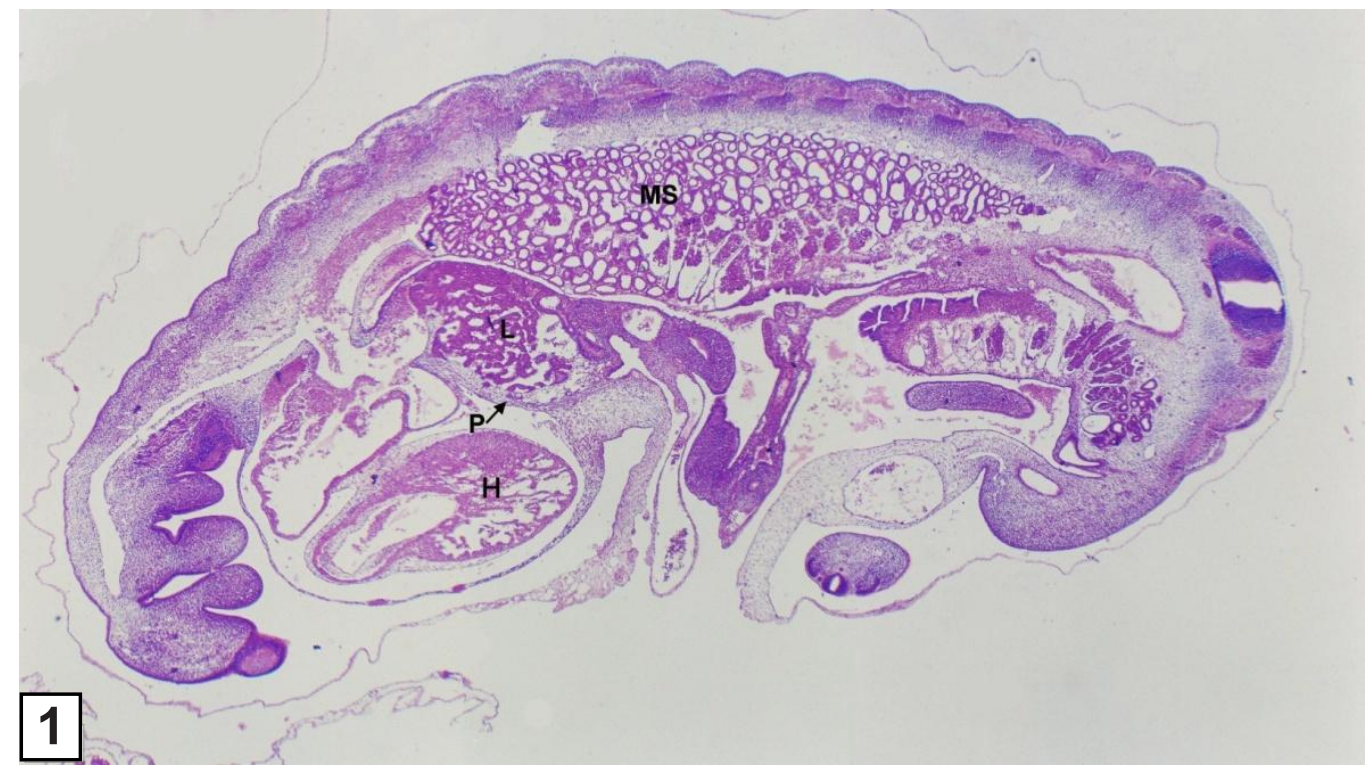

Fig (1): Sagittal section in a camel fetus of $7 \mathrm{~mm}$ CVR length, the primordium of the liver(L), pericardium (P) ,mesonephrous (Ms).(Haematoxylin \& eosin stain x 25 )

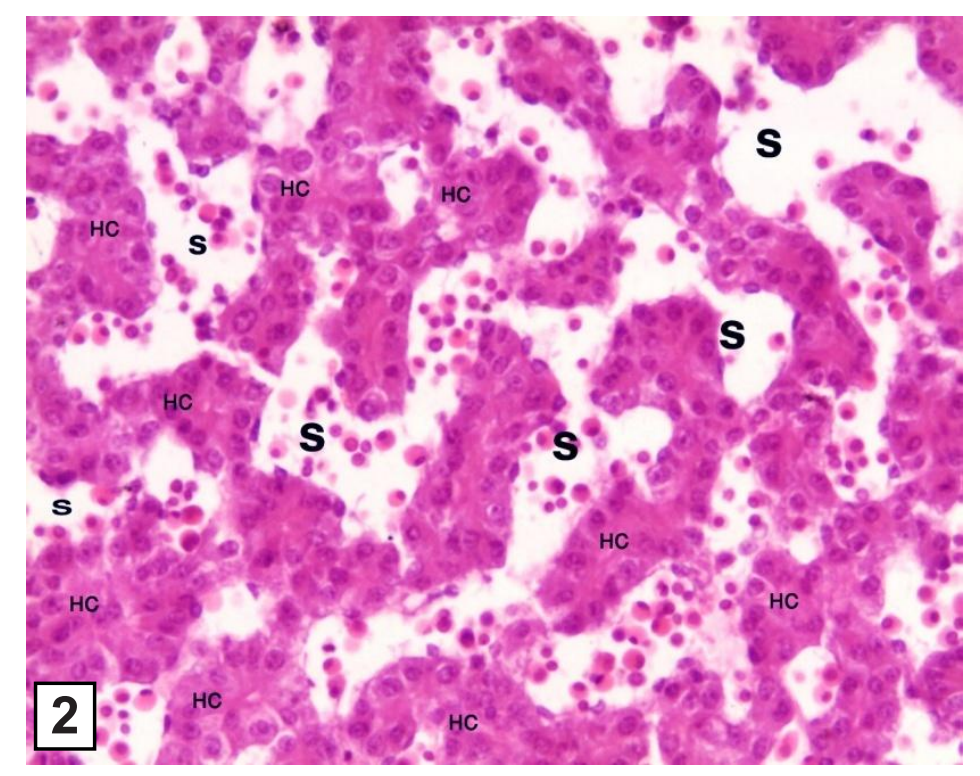

Fig (2): Liver parenchyma in a camel fetus of $7 \mathrm{~mm}$ CVR length, Hepatcytes(HC),Blood spaces(S). (Haematoxylin \& eosin stain $x$ 200) 

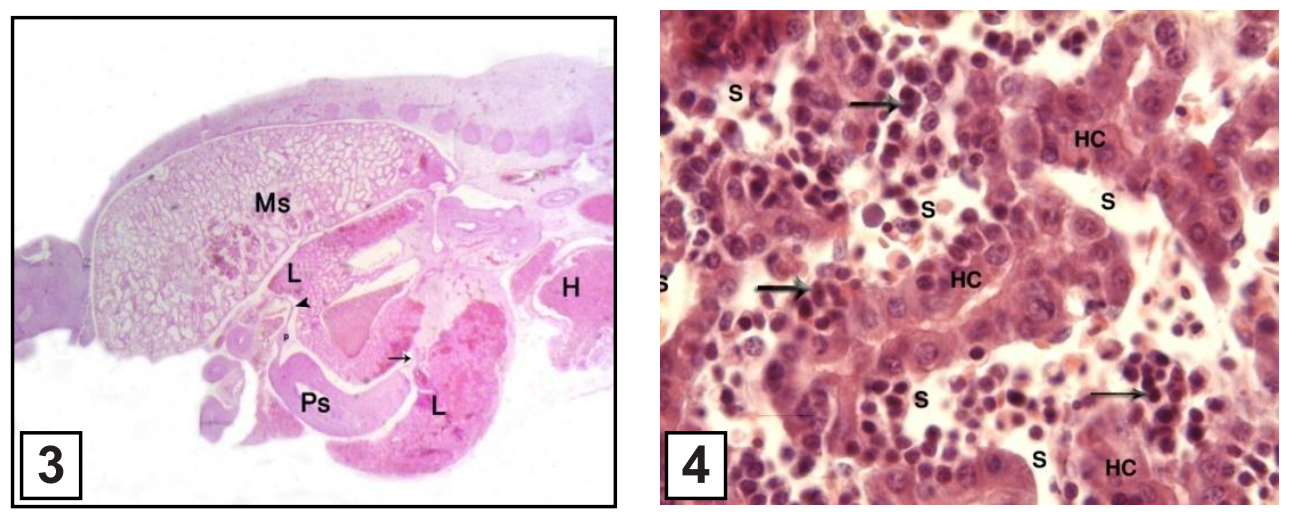

Fig (3): Sagittal section in a camel fetus of $12 \mathrm{~mm}$ CVR length, the liver(L), pericardium (P) ,mesonephrous (Ms), Septum transversum(St), Heart(H), Primitive Spleen(SP), Primitive Stomach(PS),Lesser omentum (LO).(Haematoxylin \& eosin stain x 25 )

Fig (4): Liver parenchyma in camel fetus of $12 \mathrm{~mm}$ CVR length, Hepatocytes(HC),Blood spaces(S),Haemopoietic foci(arrow).(Haematoxylin \& eosin stain x 200)
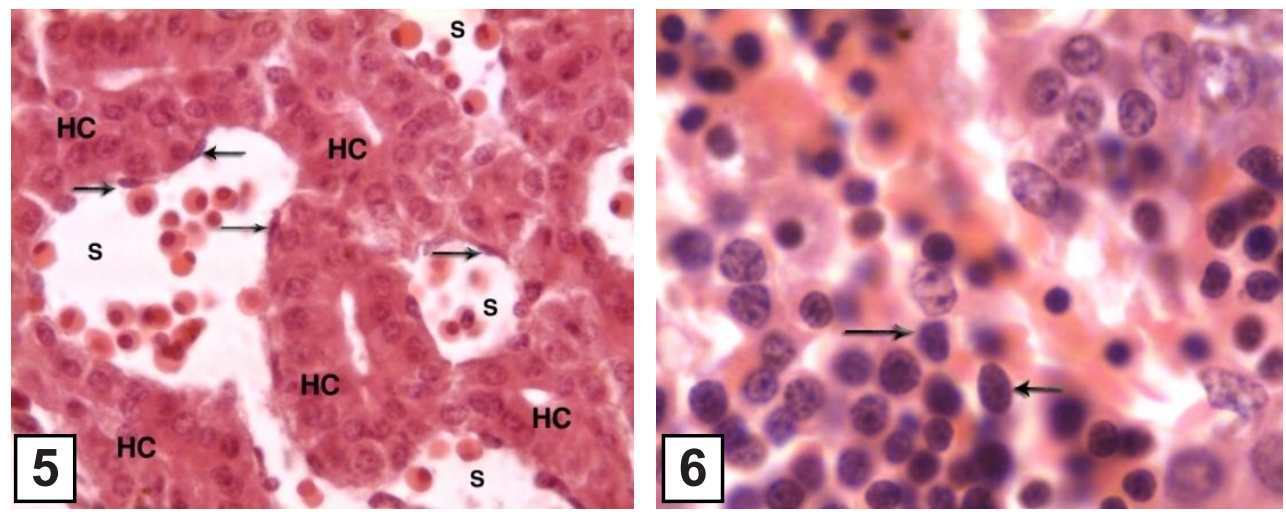

Fig (5): Liver parenchyma in camel fetus of $12 \mathrm{~mm}$ CVR length, Hepatcytes(HC),Blood spaces(S),Primitive endothelium(arrow).(Haematoxylin \& eosin stain x 400 )

Fig (6): Liver parenchyma in camel fetus of $12 \mathrm{~mm}$ CVR length, Haemopoietic cells appear rounded with deeply stained nuclei (arrow). Haematoxylin \& eosin stain x 1000 


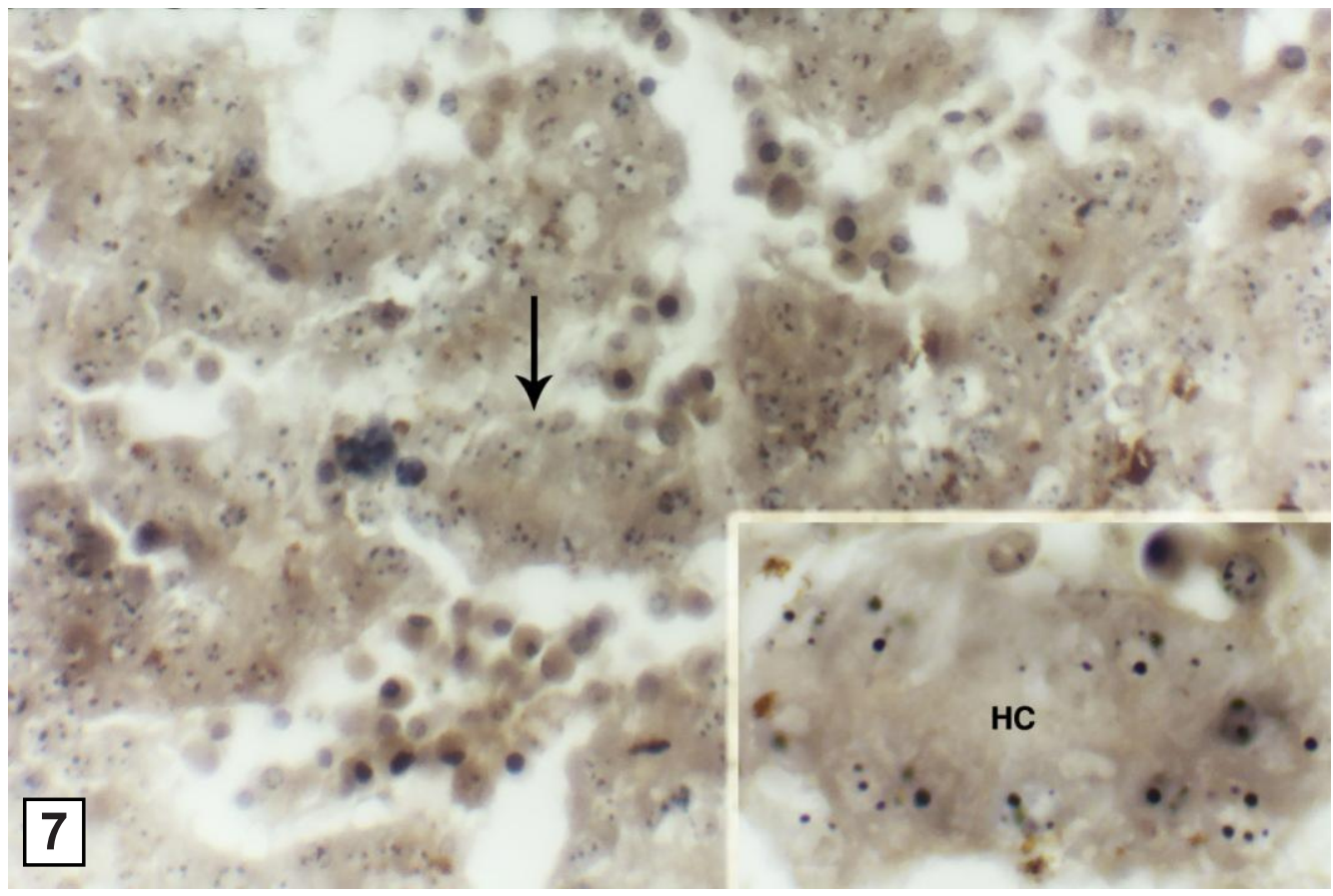

Fig (7): The liver parenchyma in camel fetus of $12 \mathrm{~mm}$ CVR length, Showing black granules of mitochondria in the cytoplasm of hepatocytes (arrow). (Iron haematoxylin stain $\times 200 \& \times 1000$ )

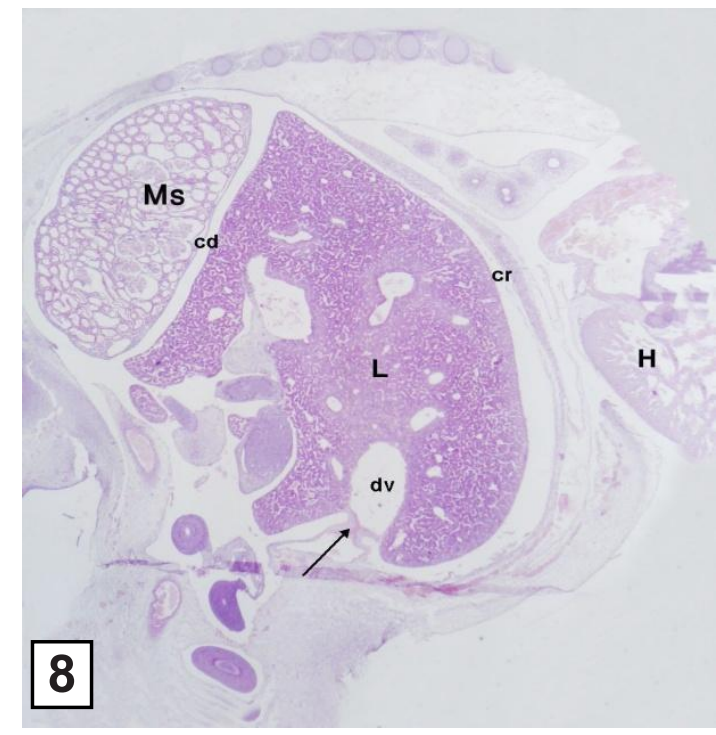

Fig (8): Sagittal section in camel fetus of $38 \mathrm{~mm}$ CVR length, Cranial surface(cr), caudal surface $(\mathrm{cd})$, Umblical vein(arrow), Ductus venosus(dv), mesonephrous (Ms), Heart(H). (Haematoxylin \& eosin stain $\times 25$ ) 

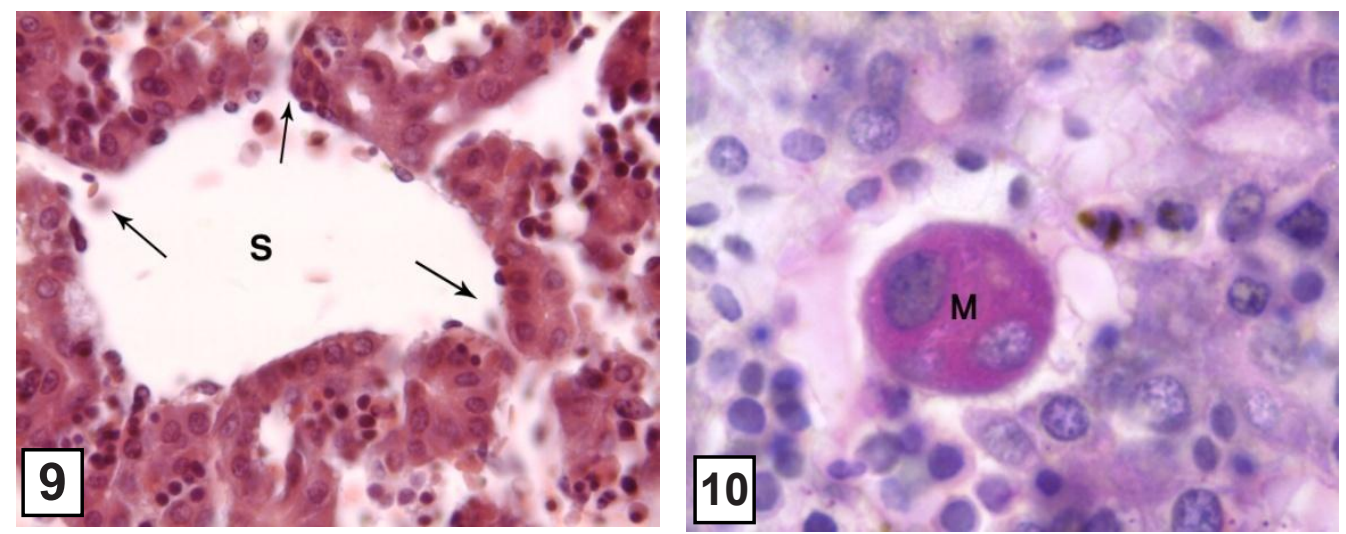

Fig (9): The liver parenchyma of camel fetus of $38 \mathrm{~mm}$ CVR length, Large irregular wide blood spaces(S) continous with slit like opening into liver sinusoids (arrows). (Haematoxylin \& eosin stain x 400)

Fig (10): The liver parenchyma of camel fetus of $25 \mathrm{~mm}$ CVR length, Megakaryocytes (M) show PAS positive reaction while surrounding hepatocytes were faintly stained. (PAS Haematoxylin stain x 1000).
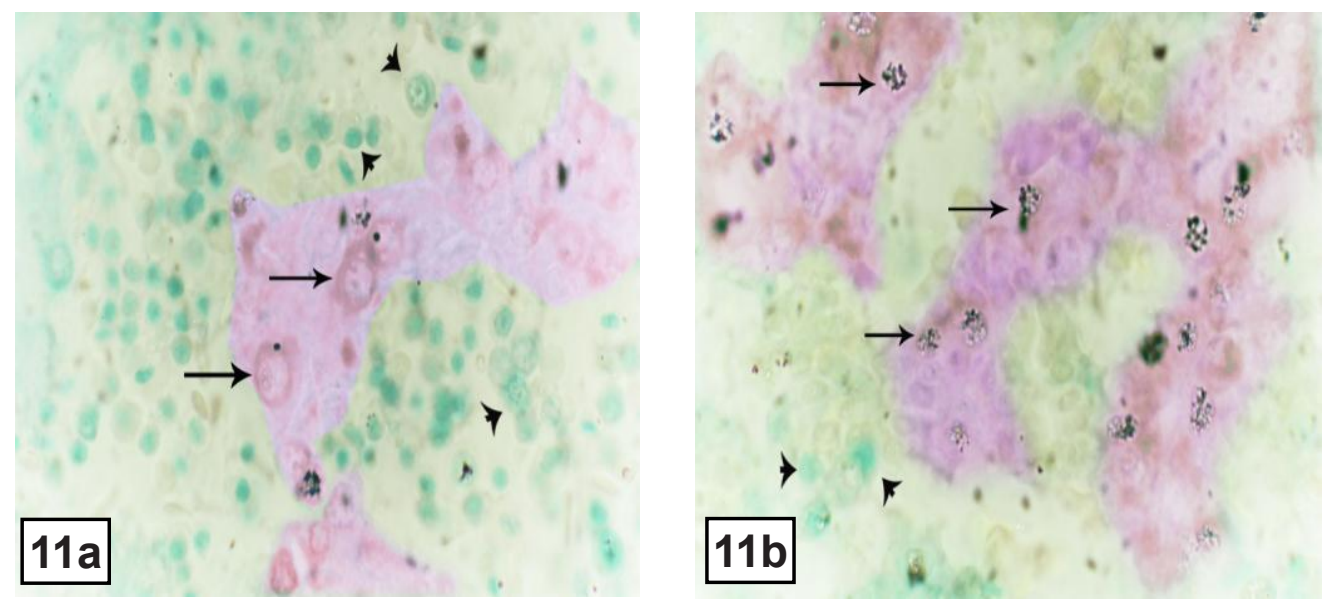

Figs (11a\&b): Liver parenchyma in camel fetuses of 25 \& $185 \mathrm{~mm}$ CVR length, Showed the RNA in the cytoplasm of hepatocytes and haempoietic cells showed very distinct pyrinophilia (arrows) and the DNA in the nuclei showed positive reaction to methyl green (arrow heads)

(11A) 25 mm CVRL, (11B) 185 mm CVRL.(Methyl Green Pyronin x 1000) 

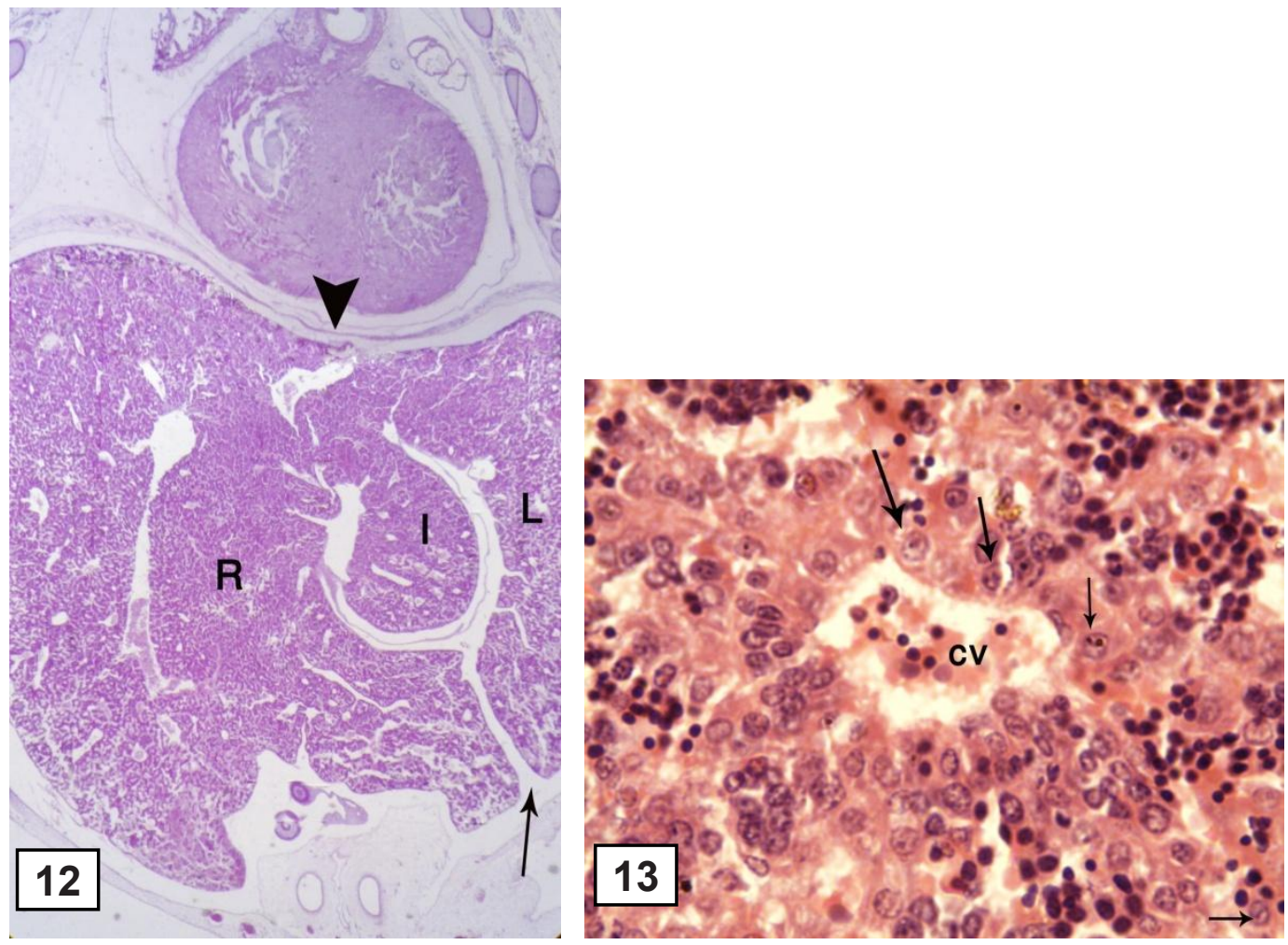

Fig (12): Frontal section in camel fetus of $50 \mathrm{~mm}$ CVR length, Lobation of the liver, a deep fissure (arrow), (R)right lobe,(I) intermediate lobe,(L) left lobe, Diaphragm ( head arrow). (Haematoxylin \& eosin stain $\times 25$ )

Fig (13): Liver parenchyma of camel fetus of $75 \mathrm{~mm}$ CVR length, Hepatic cords arranged themselves radially around developing central vein $(\mathrm{CV})$, cells show mitosis (arrows).(Haematoxyline \& eosine stain x 200 )

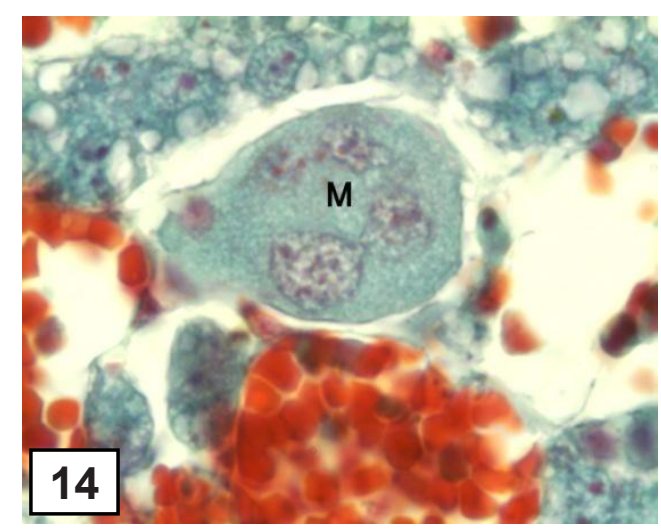

J. Vet. Anat.
Fig (14): Liver parenchyma in camel fetus of $50 \mathrm{~mm}$ CVR length, Megakaryocytes were large in size with lobulated nucleous(M).

(Crossmon's trichorome stain $\times 1000$ 

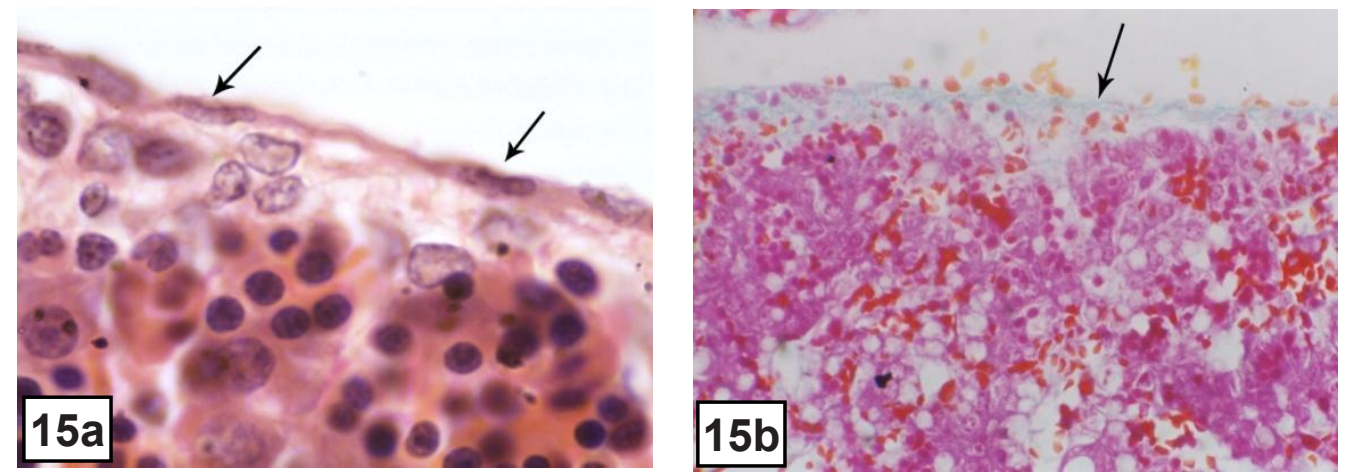

Figs (15 a,b): The primordium of Glisson's capsule in liver camel fetus of $75 \mathrm{~mm}$ CVR length ,show the mesenchymal cell of the capsule,(arrows in fig a) and few collagenous fibers under the cells, (arrows in fig b).

(a, Haematoxylin \& eosin stain $\times 1000$ )

(b, Crossman's trichorome stain $\times 200$ )

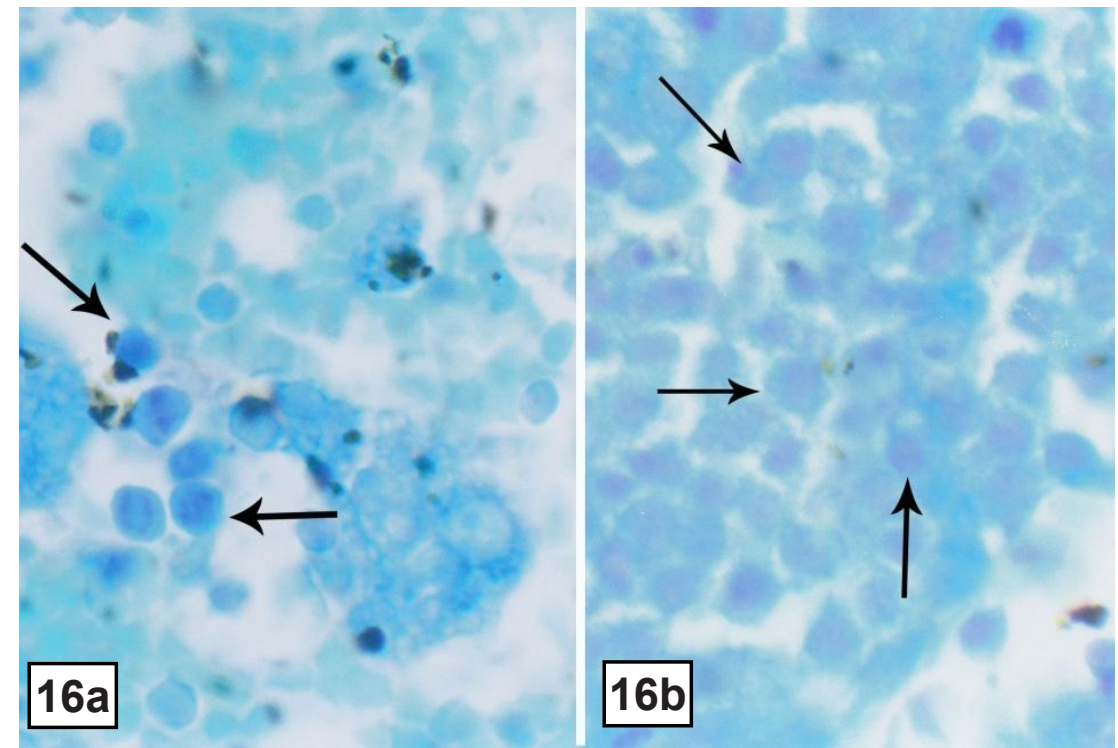

Figs (16 a,b): Mast cells among hepatocytes in camel fetus of $50 \& 125 \mathrm{~mm}$ CVR length(arrows). (16a,50 mm \&b 125mm, Giemssa stain x 1000 ). 


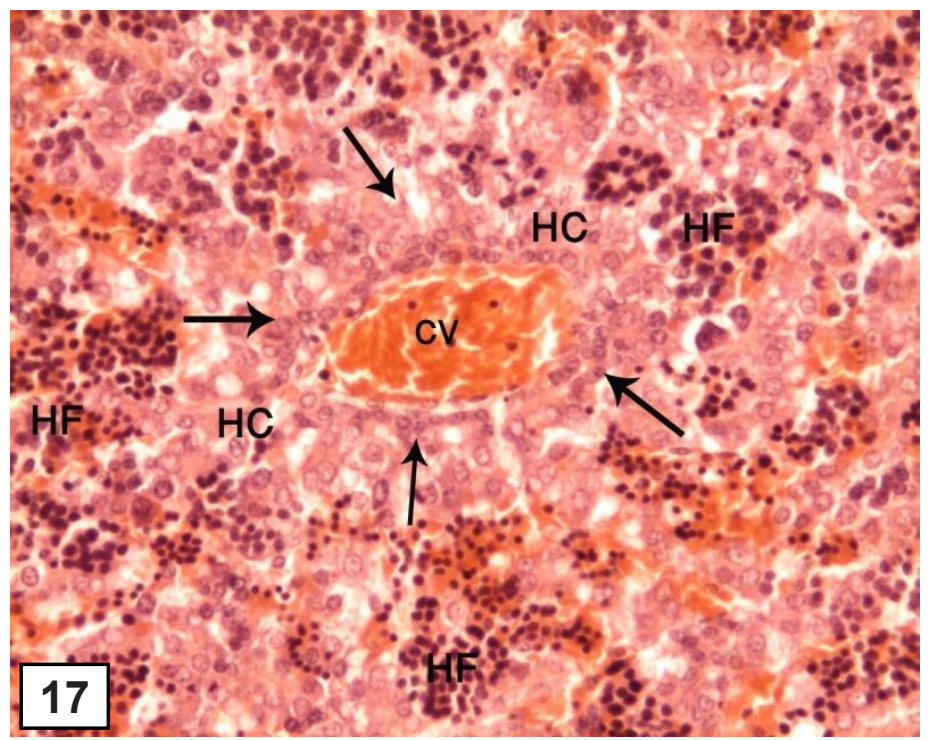

Fig (17): The liver parenchyma in camel fetus of $185 \mathrm{~mm}$ CVR length, Showed, a well defined hepatic laminae (arrows) arranged themselves in radiating rows around the central veins (CV). Hepatocytes(HC), Haemopoietic foci (HF).

Note: central vein filled with mature red blood cells. Haematoxylin \& eosin stain x 400
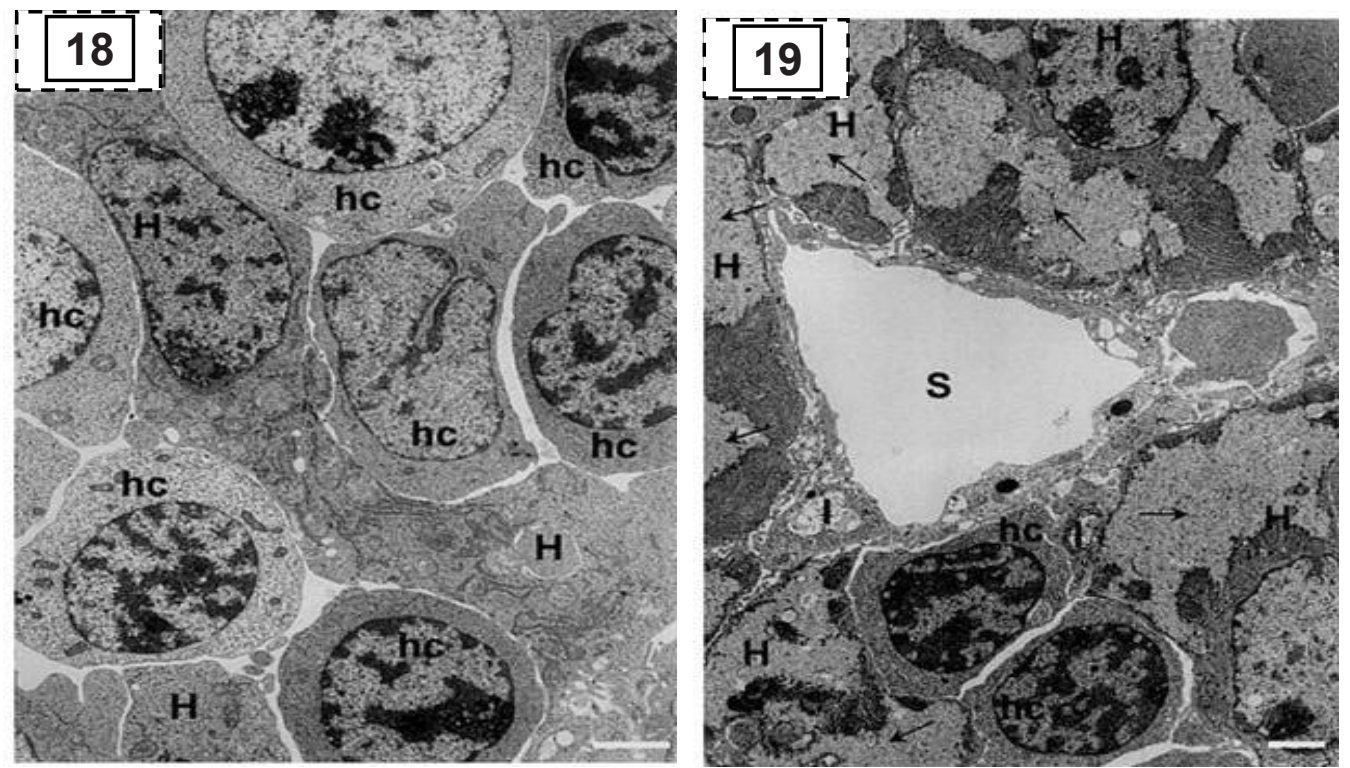

Figs (18\&19): Ultrastructural studies of fetal camel liver at $125 \& 185 \mathrm{~mm} / \mathrm{CVR}$ lengths respectively. Showing $(\mathrm{H})$ hepatocytes, (hc) haempoietic cells, (S) blood sinusoids and (arrows) glycogen droplets. Bar $=1 \mu \mathrm{m}$. 